\title{
Students' learning style and its effect on blended learning, does it matter?
}

\author{
Nurasma' Shamsuddin ${ }^{1}$, Jasber Kaur ${ }^{2}$ \\ ${ }^{1}$ Faculty of Computing and Informatics, Multimedia University-MMU Cyberjaya, Malaysia \\ ${ }^{2}$ Faculty of Computer and Mathematical Sciences, Universiti Teknologi Mara, Malaysia
}

\section{Article Info \\ Article history: \\ Received Dec 3, 2019 \\ Revised Feb 5, 2020 \\ Accepted Feb 24, 2020}

\section{Keywords:}

Blended learning

Learning style

Online learning

\begin{abstract}
Blended learning is an approach in education system that provides multi delivery mode to optimize learning outcome and cost of program delivery in institutions. Little is known on how impactful blended learning in terms of achieving the desired learning outcome. This is because students' learning style has influenced their achievement and if mediated in a hybrid learning environment like blended learning will further result in evaluation and performance of blended learning environment. This study aims to investigate learning styles among the students and their relationship with perceptions of blended learning. The study involved 119 students taking the course of Diploma in Information Technology at a private university. The learning style of the students was determined by using Kolb's Learning Style Inventory, while perceptions of blended learning were investigated using elements of process, content, and usability. Student perceptions on blended learning were assessed using a one-way ANOVA to determine the correlation with the learning style of the students. Majority of the students belong to the Convergent category, followed by Divergent, Accommodator, and Assimilator. The outcomes of this study showed no meaningful difference between students' learning styles and their perceptions towards blended learning. The findings from the study could benefit academician in designing more suitable material according to students' preferred mode such as more hands-on tasks for Convergent groups, which belief, can improve the student's achievement.
\end{abstract}

This is an open access article under the CC BY-SA license.

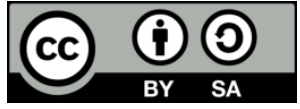

\section{Corresponding Author:}

Nurasma' Shamsuddin,

Faculty of Computing and Informatics,

Multimedia University-MMU Cyberjaya,

Persiaran Multimedia, 63100 Cyberjaya, Selangor, Malaysia.

Email: nurasma.shamsuddin@mmu.edu.my

\section{INTRODUCTION}

One of the goals stated in the Education Blueprint for Malaysia 2013:2025 is to produce more universal and all-rounded persons who will be able to survive in a competitive global economy [1]. Thus, a transition from the common traditional delivery method towards a technology implementation to personalize the learner's experience deemed essential. Blended learning (BL) is the chosen core pedagogical method to ensure such effective transition. Research conducted at a private university in Malaysia showed a satisfactory level of usage of ICT technology by students in the BL environment [2, 3]. However, the online engagement level was still low and requires some room for improvements. Generally, the usage of ICT tools enhanced the students' learning experience and created a conducive learning environment. 
Blended Learning integrates of traditional face-to-face and online learning [4]. According to Clark and James [5], BL is "based on the assumption that there were inherent benefits in face-to-face interaction as well as the understanding that there were advantages to using on-line methods". By implementing BL, the learning sessions will become more genuine and significant for the students as it combines in-class traditional methods and computer technology components in learning activities. Besides, the students can define their goals, make decisions, and evaluate their progress when there is an injection of technology during the student's activities [6]. BL is not just a strategy of replacing hardcopy paper assignments with digital worksheets, thus it is necessary for educators to know the role and purpose of online learning and balance the between traditional class time and adapting the e-learning as the technology changes.

\section{Blended learning}

Oxford Dictionary defines "blend' as "mix (a substance) with another substance so that they combine together". Consequently, the definition in the BL context is about the combination of traditional in-class and web component usage in producing a course that utilizes both worlds of the instruction. BL can be considered as a combination of multiple deliveries with the objective of optimization of the outcome of the learning together with the expenses. BL only emphasizes achievement optimization by implementing the right technology to match the right individual learning preference so that the right skills can be transferred to the right person at the right time [7]. Variety of teaching and learning tasks, including in classroom activities, online learning and self-study can be mixed in BL [8]. Basically, from the definition, it is not to interrupt the traditional face-to-face environment by the teacher, but to blend with collaboration, technology, and the human.

\section{Blended learning in higher education}

Many higher education are now implementing BL by offering a variety of programs that apply both online and in-class activities. Digital technologies such as the Internet, email, notebook, and smartphones have affected several developments in the teaching and learning process in the majority of tertiary education. Utilisation of Web resources in teaching and learning provides greater flexibility in interaction during the learning process. The amount of face to face teaching modules have been substituted with Web materials is varied depending on university and instructor. There is no fixed rule on how much or what parts of a program that need to use web components [9]. BL can be utilized for those programs that created for students in the distance, which prevents them from attending in classroom delivery programs [10]. By implementing BL, higher education can still keep the high standards and accreditation while the extra flexibility can be provided to the students. The number of higher education implementing BL is increasing rapidly and there is an estimation that from 80 to 90 percent of the course will be hybrid someday [11].

\section{Learning style}

Academic achievement of a student does not depend on intellectual ability but also on the individual's unique learning styles [12]. According to Federico [13], there is no one instructional strategy that can fit for all students. He stated that "Students will be able to achieve learning goals more efficiently when pedagogical procedures are adapted or accommodated to their individual differences".

Smith and Dalton [14] define learning style as a"distinctive and habitual manner of acquiring knowledge, skills or attitudes through study or experience".

Keefe [15] defines learning style as the combination of cognitive, emotional and psychological characteristics of learners that work as coherent indicators learners' perception of their learning environment, how they interact with and respond to their surroundings. Felder and Silverman [16] stated that learning style is a learner preference and strength characteristic that they favor while processing knowledge. Learning style can be described as a technique favored by a person during the acknowledgment and handling of a particular slice of data which include both mental and emotional dimension [12].

Many studies suggest that each individual has its own learning style. For an educator, by knowing learning styles, it can help to identify and resolve student learning problems [17]. This will encourage the students to learn more efficiently as the educator able to match the education material with the students' learning style.

\section{Learning style and blended learning}

From the literature, there were many obstacles recorded regarding the BL implementation such as the students, educators and system factors. A study conducted by Maarop and Embi [18] found that student's participation is the main barrier in blended implementation. Few factors such as level of discipline and responsiveness of the students, poor time management and diversity of students' backgrounds affect their participation in BL [18]. 
According to Goodridge, Lawanto and Santoso [19], one of the factors that impacts on the synchronous online deliverable engineering graphics curriculum is concerns on learning styles but there is not so much investigation on it. Moreover, Cheng and Chau [20] work showed that individual learning styles affect the student's participation in BL activity as students prefer to participate in the activity that fits with their learning preferences. Other findings from Vasileva-Stojanovska, Malinovski, Vasileva, Jovevski, and Trajkovik [21] stated that different learning environment needs to be constructed depending on learning styles to get optimal outputs on educational outcome.

With the emergence of digital technology, teaching style using multimedia-based has been emphasized. Unfortunately, not every student able to use the material well and their learning styles influence their learning achievement [22]. Therefore, more research is needed regarding the impact of learning styles towards the BL environment especially in Malaysian context.

Different models portray different learning styles that have been proposed to improve individuals' understanding such as Kolb [12], Felder and Silverman [16] and VARK [23]. These are the three popular learning styles model that usually being used to assess the learning preference of adult students [24]. Within the scope of this study, Kolb's Learning Style was selected to identify the students' learning style as it has extensively been used in previous work on web-based learning, e-learning and BL [25-29]. This paper presents the relationship between the Kolb's learning style among the students and their relationship with perceptions of blended learning.

Kolb's learning style

Kolb's Learning Style model is a combination of cognition, experience, perception, and behavior. There are four categories of learning modes or orientations in the model which are concrete experience $(C E)$, reflective observation $(R O)$, abstract conceptualization $(A C)$ and active experimentation $(A E)$. The concrete experience learning model emphasizes learning through experience, while reflective observation is involved learning through observation, abstract conceptualization emphasizes learning through thinking and active experimentation focuses on learning by doing [26].

Learning styles in Kolb's can be categorized as divergent, assimilator, convergent and accommodator which each learning style is a combination of two learning modes. The Divergent learning style is a resultant of reflective observation and concrete experience and is those who prefer to "watch" and "feel". These group of people are capable of revising concrete situations from different angles and take their thoughts and feelings into consideration. These types of people are objective, patient, and suited in a various artistic field such as psychology, literature, nursing, media, theatre, design, journalism, and social work $[19,30,31]$.

The Assimilator learning style consists of reflective observation and abstract conceptualization that can be qualified as "think" and "watch". The main characteristic of this type of person is creating conceptual models as they love conceptualization and abstract ideas. They are suited to educational research, mathematics, sociology, theology, law, physical sciences, and biology [19, 30, 31].

The Convergent learning style is a mixture of abstract active experimentation and conceptualization and fall within "think" and "do". They are people that successful in terms of solving problems, deciding with systematic planning and apply ideas through practical. These types of people are committed to medical technology, computer science, engineering, accounting, economics, environmental sciences, and agriculture and forestry $[19,30,31]$.

The Accommodator learning style are those individuals with high ratings in the fields of active experimentation and concrete experience and they can be considered as "feel" and "do". Individual learning in this style are open-minded, like new experiences, planning and easily adapt to change. These people also prefer to act on feeling and suited to education, management, public finance, marketing, human resources, and public administration $[19,30,31]$.

Learning styles change over time, thus, by considering the different learning style, all the teaching materials, class environment, the methods, and strategies can be prepared accordingly. This will be much more efficient as the student learning experience will be improved than expecting the students themselves adapting to the surrounding [30]. In the preparation and usage of BL, learning styles are significant, consequently, this research focuses on learners' learning styles.

The inventory of Kolb's learning style was chosen in this research for multiple reasons. Firstly, Kolb's [12] learning style inventory, has been practiced in e-learning or web-based learning research [25, 27 , 32-34] to assess students preferences in two bipolar concepts. When skills and information are acquired over time, Kolb propose that students would prefer either concrete experience or abstract conceptualization. Learners may develop preference in practical by active experimentation, or they emphasize about their experiences by reflective observation [30]. Thus, Kolb learning style will be used in this study to assess students based on their learning experiences and further explore its relationship with BL environment. 


\section{RESEARCH METHOD}

The purpose of this study is to determine the relationship between students' learning style with their perception towards BL, thus the research takes on quantitative research. This study's conceptual model is shown in Figure 1.

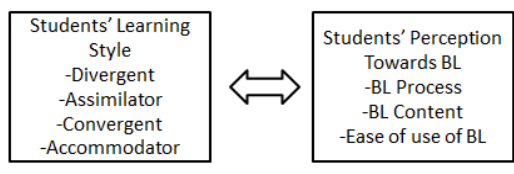

Figure 1. Conceptual model

The research was carried out at a Malaysian private higher learning institution. The sampling included 119 students of Diploma in Information Technology that uses BL method for teaching and learning process. The mapping of research methods and deliverables with their own objectives is shown in Table 1.

Table 1. The mapping of research question, objectives, methods \& deliverables

\begin{tabular}{|c|c|c|c|}
\hline Research Question & Research Objective & Method/Techniques/Tools & Deliverables/outcomes \\
\hline $\begin{array}{l}\text { Q1. } \\
\text { What are the learning styles } \\
\text { found among students? }\end{array}$ & $\begin{array}{l}\text { To assess the } \\
\text { learning style among } \\
\text { students in MMU }\end{array}$ & $\begin{array}{l}\text { Data Collection: } \\
\text {-Kolb's Learning Style Inventory }\end{array}$ & $\begin{array}{l}\text { List of students' learning style } \\
\text { (Divergent, Assimilator, } \\
\text { Convergent, and } \\
\text { Accommodator) }\end{array}$ \\
\hline $\begin{array}{l}\text { Q2. } \\
\text { Are there any significant } \\
\text { different in learning style } \\
\text { when using BL? }\end{array}$ & $\begin{array}{l}\text { To examine the } \\
\text { relationship between } \\
\text { students' learning } \\
\text { style when using } \\
\text { blended learning }\end{array}$ & $\begin{array}{l}\text { Data Collection: } \\
\text {-Blended learning Questionnaire } \\
\text { (survey) } \\
\text { Data Analysis: } \\
\text {-Descriptive statistic } \\
\text {-One-way ANOVA analysis using } \\
\text { SPSS }\end{array}$ & $\begin{array}{l}\text {-Students' perception score for } \\
\text { BL } \\
\text {-Students' perception score for } \\
\text { BL according to learning style } \\
\text { group } \\
\text {-Relationship between students' } \\
\text { learning style and blended } \\
\text { learning usage statistic }\end{array}$ \\
\hline
\end{tabular}

\subsection{Research instrument}

To discover the answer for the research questions, Kolb's Learning Style Inventory (LSI) and a fivepoint Likert-scale BL questionnaire were used to gather data. The learning style questionnaire adapted from Kolb's Learning Style Inventory (1986) was used to determine the learning style of each student. The inventory consists of a 12-item questionnaire applicable to youths and adult learners. Each item has four expressions of answers, which respondents are demanded to give a score (from 4 to 1 ) to each expression; starting from the best characteristic to the least characteristic. The LSI was conducted using "Online Google Form" to the respondents in enough time by giving them the required explanations earlier. The scores are given by the students for $\mathrm{CE}, \mathrm{AC}, \mathrm{RO}$, and $\mathrm{AE}$ were added, and then $\mathrm{AC}-\mathrm{CE}$ and $\mathrm{AE}-\mathrm{RO}$ were calculated to determine students' preferred style of learning. The reliability coefficient of the Inventory for concrete experience (CE), reflective observation (RO), abstract conceptualization (AC), and active experimentation (AE) were $.81, .78, .83$, and .84 , accordingly $[35,36]$.

The BL questionnaire was adapted from Shantakumari and Sajith [37]. There are three main categories in the questionnaires. The first 10 statements aim to highlight the perception of students in BL process. The following 9 statements aim to identify the perception of the BL content and the remaining 5 statements aim to determine student's perceived use of computer and web environment. Using a 5-point Likert scale (strongly agree, agree, neutral, disagree and strongly disagree), the scores were computed as four points, three, two, one, and zero, accordingly. The coefficient of the reliability of the scale was determined as .87 , it shows that the tool was reliable [37]. Other demographic information recorded included gender, date of birth and registered course. Open-ended questions also being asked to highlight whether is there any difficulties the student had faced or benefits they obtained by the implementation of a BL method to the course delivery.

\subsection{Data analysis}

Data in Excel spreadsheets was analyzed using IBM Statistical Package for Social Sciences (IBM SPSS Statistics 25.0). Descriptive statistics and one-way variance analysis, One-way ANOVA were used with a significance level. Besides this, feedback from open-ended questions were analyzed and reported as part of the findings.

Int. J. Eval. \& Res. Educ. Vol. 9, No. 1, March 2020: 195 - 202 


\section{RESULTS AND DISCUSSION}

The descriptive statistics showed that $23 \%$ (27/119) of the students were females, and $77 \%(92 / 119)$ were males. The student's age ranged between 17-26 years.

\subsection{What are the learning styles found among students?}

The research examined the students' learning style and findings as shown in Figure 2 showed that $34 \%(40 / 119)$ of the students categorized into the group of convergent, 24\% (29/119) were divergent, $21 \%(25 / 119)$ were accommodator, and $21 \%$ (25/119) were assimilator.

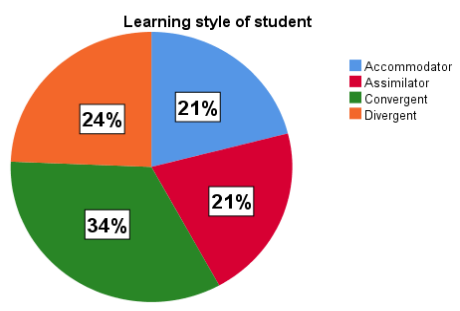

Figure 2. Percentage of students' learning style

\subsection{Are there any significant differences in learning style when using blended learning?}

Firstly, the discussion will start regarding the average values pertaining the students' perception of blended learning on three domains as presented in Table 2. The following Table 2 presents mean scores on students' perception on BL based on process, content and ease of use.

Table 2. Students' perception of blended learning $(\mathrm{n}=119)$

\begin{tabular}{lll}
\hline Domains & Mean & SD \\
\hline BL process & 2.53 & 0.64 \\
BL content & 2.66 & 0.61 \\
Ease of use of web environment & 2.82 & 0.67 \\
Overall & 2.67 & 0.56 \\
\hline
\end{tabular}

The average score of students' perceptions on BL process is 2.53 , while the mean score for the BL content and ease of use of BL are 2.66 and 2.82 respectively. Overall mean score is 2.67 which suggest that students have an average perception of BL. Students agree that BL is a new and interesting way of learning new things in an easy way and yet less time consuming as compared with traditional classes. BL promotes independence and self-learning orientation.

As this research purpose is to examine whether there are any differences in learning style when using BL, the descriptive statistical result for student's BL score on the three BL domains according to their learning style are shown in Table 3.

Table 3. Descriptive summary of students' perception of blended learning with learning style $(n=119)$

\begin{tabular}{lllll}
\hline Blended Learning Perception & Learning Style & N & Mean & SD \\
\hline BL process & Accommodator & 25 & 2.50 & 0.56 \\
& Assimilator & 25 & 2.32 & 0.65 \\
& Convergent & 40 & 2.68 & 0.65 \\
& Divergent & 29 & 2.54 & 0.66 \\
& Total & 119 & 2.53 & 0.64 \\
\hline BL content & Accommodator & 25 & 2.59 & 0.64 \\
& Assimilator & 25 & 2.61 & 0.53 \\
& Convergent & 40 & 2.76 & 0.62 \\
& Divergent & 29 & 2.64 & 0.64 \\
& Total & 119 & 2.66 & 0.61 \\
\hline Ease of use of the web environment & Accommodator & 25 & 2.84 & 0.67 \\
& Assimilator & 25 & 2.84 & 0.67 \\
& Convergent & 40 & 2.90 & 0.60 \\
& Divergent & 29 & 2.67 & 0.77 \\
& Total & 119 & 2.82 & 0.67 \\
\hline Overall students' perception of BL & Accommodator & 25 & 2.64 & 0.52 \\
& Assimilator & 25 & 2.59 & 0.49 \\
& Convergent & 40 & 2.78 & 0.56 \\
& Divergent & 29 & 2.61 & 0.65 \\
& Total & 119 & 2.67 & 0.56 \\
\hline
\end{tabular}


The results show that highest positive value towards the BL process belongs to the Convergent group while the Assimilator group ranks lowest. As for the BL content, the Convergent group once again dominates the score followed by Divergent, Assimilator and Accommodator group. While for the third domains, still, Convergent group ranks highest, Assimilator and Accommodator were a tie and Divergent ranks lowest. Three students from the Assimilator learning category found that BL implementation as learning medium is difficult as there are subject matter that is difficult to understand. Whilst three other students from Convergent learner gave a more positive outcome regarding BL implementation as easy and quick way to learn with plenty of self-learning opportunity without time constraints.

However, the average rates as shown in Table 3, illustrates that students in all four groups of learning styles are quite similar. Thus, to decide whether the scores given by students vary according to their learning styles, variance analysis (ANOVA) was executed and outcomes are produced in Table 4. ANOVA results shows that students' perceptions of BL presents no significant difference among learning styles, $\mathrm{F}(3,115)=0.808$ and $\mathrm{p}=0.49$.

Table 4. ANOVA on students' perception of blended learning with learning style ( $\mathrm{n}=119)$

\begin{tabular}{lllllll}
\hline $\begin{array}{l}\text { Blended Learning } \\
\text { Perception }\end{array}$ & & $\begin{array}{l}\text { Sum of } \\
\text { Squares }\end{array}$ & df & $\begin{array}{l}\text { Mean } \\
\text { Square }\end{array}$ & F & Sig. \\
\hline \multirow{3}{*}{ BL Process } & Between Groups & 2.071 & 3 & 0.690 & 1.702 & 0.170 \\
& Within Groups & 46.628 & 115 & 0.405 & & \\
& Total & 48.699 & 118 & & & 0.682 \\
& Between Groups & 0.566 & 3 & 0.189 & 0.501 & \\
\hline \multirow{3}{*}{ BL Content } & Within Groups & 43.331 & 115 & 0.377 & & 0.562 \\
& Total & 43.897 & 118 & & & \\
\hline Ease of Use & Between Groups & 0.937 & 3 & 0.312 & 0.686 & 0.492 \\
& Within Groups & 52.342 & 115 & 0.455 & & \\
\hline Overall & Total & 53.279 & 118 & & & \\
& Between Groups & 0.760 & 3 & 0.253 & 0.808 & 0.314 \\
& Within Groups & 36.065 & 115 & 0.314 & & \\
\hline
\end{tabular}

Students' perception on BL as according to groups of Accommodator, Assimilator, Convergent and Divergent also quite similar. This result valid with the answers given by a student from the open-ended question. The following are the student's answers about the difficulties met during course delivery using BL:

Accommodator: "Nothing serious". are needed".

Assimilator: "I do not have any difficulties on the course. Only more learning and practice

Convergent: "No, no difficulties".

Divergent: "No I do not".

When the students' from the different groups of learning style were asked about the benefits gained from this BL delivery method, they responded to similar perceptions;

Accommodator: "I put more effort in studying rather than in normal class".

Assimilator: "Easy to understand without any disturb noises".

Convergent: "The time management becomes easier".

Divergent: "Better time management. On some weeks or days where students are required to focus more on other particular subject, the time available when there's no traditional in-class lesson helps to give space for them to complete the required task for that other subject."

In regards to the online environment, the student's responses from the different group of learning styles are shown below:

Accommodator: "You can always do whenever you are before the dateline".

Assimilator: "I will explore more by searching through the internet".

Convergent: "No papers were used \#saveearth".

Divergent: "All information is available at your fingertip".

From the results, it shows that students were aware of the difference between BL and traditional in class delivery method. Few answers that recorded mostly reflect in terms of flexibility to learn without being physically in class. The answers are given below:

Assimilator 1: "No need to walk to class".

Assimilator 2: "Don't have to go to class".

Convergent: "Less energy used in driving to class and being able to take your time thinking and solving the question".

Divergent: "Don't have to travel to campus". 
Based on previous studies, some researchers have emphasizes concerns about students' learning styles as one of the factors to determine the success of BL implementation as it can help improve students' learning and also increase student's achievement $[17,19,31,38]$. As an educator, it is part of your responsibility to know your students learning preference as it will be able to help the students to be more effective both in the classroom and outdoors [17].

\section{CONCLUSION}

In this study, the student's population was categorized into four groups of Kolb's learning styles, Accommodator, Assimilator, Convergent and Divergent. Accommodators have the most practical approach whereby they prefer doing rather than thinking; Assimilators are people that have most cognitive approach as when they learn they prefer organized and structured understanding and lectures, reading, writing, also individual work are their preference. Convergent has a strong ability in thinking and they will try to see if their ideas work in practice. They love fact and preferred to work along and independent; Divergent have the greatest strength in terms of diverging a single experience to multiple possibilities and they are keen to receive productive feedback.

The student's mean score on three domains of BL; process, content, and ease of use shows positive perceptions and the results were validated with the comments given from open-ended questions. The students' perceptions of BL according to each learning style also generally positive where Convergent ranks highest follow by Accommodator, Divergent and Assimilator.

Therefore, in this study, the relation of the students' perceptions of BL in terms of their learning styles was evaluated. However, after executing a one-way analysis of variance (one-way ANOVA), no significant difference was found between students' learning style and their scores for BL at least in this diploma in IT programme. The student's answer given to the open-ended questions also aligns with this finding which is generally positive about BL regardless which learning style they are belongs to.

This study has several limitations. The respondents were only focused on Diploma in IT students. Future studies could gather data from different course as to validate the outcome of this study. Another limitation is that this research used self-reported survey form, thus, naturally it depends on the accuracy of the answers given by respondents. Although the findings are valid, results should not be generalized to other higher learning institutions.

\section{REFERENCES}

[1] Ministry of Education, Malaysian Education Blueprint 2013-2025. Ministry of Education Malaysia, 2012.

[2] C.C. Wai and E.L.K. Seng, "Exploring the effectiveness and efficiency of blended learning tools in a school of business," Procedia-social and behavioral sciences, vol. 123, pp. 470-476, 2014.

[3] Azizan, F. Z., "Blended learning in higher education institution in Malaysia," In Proceedings of regional conference on knowledge integration in ICT, vol. 10, pp. 454-466, 2010.

[4] L.D. George-Walker and M. Keeffe, "Self-determined blended learning: a case study of blended learning design," Higher Education Research \& Development, vol. 29 no. 1, pp. 1-13, 2010.

[5] I. Clark and P. James, "Blended learning: An approach to delivering science courses on-line," In Proceedings of The Australian Conference on Science and Mathematics Education (formerly UniServe Science Conference) vol. 11, Oct 2012.

[6] Leidner, D. E., \& Jarvenpaa, S. L., The use of information technology to enhance management school education: A theoretical view, MIS quarterly, pp. 265-291, 1995.

[7] Singh, H., \& Reed, C., "A white paper: Achieving success with blended learning," Centra software, vol. 1, pp. 1-11, 2001.

[8] Singh, H., "Building effective blended learning programs," Educational Technology-Saddle Brook Then Englewood Cliffs NJ, vol. 43, no. 6, pp. 51-54, 2003.

[9] Garrison, D. R., \& Kanuka, H., "Blended learning: Uncovering its transformative potential in higher education," The internet and higher education, vol. 7, no. 2, pp. 95-105, 2004.

[10] Carroll, B., \& Hsu, L., "Going hybrid: Online course components increase flexibility of on-campus courses," Online Classroom, pp. 4-7, 2003.

[11] Young, J. R.,"Hybrid'teaching seeks to end the divide between traditional and online instruction," Chronicle of Higher Education, vol. 48, no. 28, pp. A33-A33, 2002.

[12] Kolb, D. A., Experiential learning: Experience as the source of learning and development, Upper Saddle River, Prentice Hall: N. J, 1984.

[13] Federico, P., "Learning styles and student attitudes toward various aspects of network-based instruction," Computers in Human Behavior, vol. 16, pp. 359-379, 2000.

[14] Smith, P., \& Dalton, J., Getting to Grips with Learning Styles. National Centre for Vocational Education Research Ltd. PO Box 8288, Stational Arcade, Adelaide, SA 5000, Australia, 2005. 
[15] Keefe, J. W., Learning Style Theory and Practice. National Association of Secondary School Principals, 1904 Association Dr., Reston, VA 22091, 1987.

[16] Felder, R. M., \& Silverman, L. K., "Learning and teaching styles in engineering education," Engineering education, vol. 78, no. 7, pp. 674-681, 1988.

[17] Shah, K., Ahmed, J., Shenoy, N., \& Srikant, N., "How different are students and their learning styles?" International Journal of Research in Medical Sciences, vol. 1, no. 3, pp. 212-215, 2017.

[18] A.H. Maarop and M.A. Embi, "Implementation of blended learning in higher learning institutions: A review of literature," International Education Studies, vol. 9, no. 3, pp. 41, 2016.

[19] Goodridge, W. H., Lawanto, O., \& Santoso, H. B., "A learning style comparison between synchronous online and face-to-face engineering graphics instruction," International Education Studies, vol. 10, no. 2, pp. 1-14, 2017.

[20] Cheng, G., \& Chau, J., "Exploring the relationships between learning styles, online participation, learning achievement and course satisfaction: An empirical study of a blended learning course," British Journal of Educational Technology, vol. 47, no. 2, pp. 257-278, 2016.

[21] Vasileva-Stojanovska, T., Malinovski, T., Vasileva, M., Jovevski, D., \& Trajkovik, V., "Impact of satisfaction, personality and learning style on educational outcomes in a blended learning environment," Learning and Individual Differences, vol. 38, pp. 127-135, 2015.

[22] Weng, et al., "The influence of learning style on learning attitude with multimedia teaching materials," Eurasia Journal of Mathematics, Science and Technology Education, vol. 15, no. 1, 2018.

[23] Fleming, N. D., Teaching and learning styles: VARK strategies, IGI Global, 2001.

[24] Özyurt, Ö., \& Özyurt, H., "Learning style based individualized adaptive e-learning environments: Content analysis of the articles published from 2005 to 2014," Computers in Human Behavior, vol. 52, pp. 349-358, 2015.

[25] Manochehri, N. N., \& Young, J. I., "The impact of student learning styles with web-based learning or instructorbased learning on student knowledge and satisfaction," Quarterly Review of Distance Education, vol. 7, no. 3, p. 313, 2006.

[26] Akkoyunlu, B., \& Yilmaz-Soylu, M., "A study of student's perceptions in a blended learning environment based on different learning styles," Educational Technology \& Society, vol. 11, no. 1, pp. 183-193, 2008.

[27] Sahasrabudhe, V., \& Kanungo, S., "Appropriate media choice for e-learning effectiveness: Role of learning domain and learning style," Computers \& Education, vol. 76, pp. 237-249, 2014.

[28] Patil, R., Brown, M., Ibrahim, M., Callaway, R., \& Hamidi, R., "The effects of the use of internet and phone on students' performance across different disciplines," In E-Learn: World Conference on E-Learning in Corporate, Government, Healthcare, and Higher Education, pp. 642-650, Association for the Advancement of Computing in Education (AACE), Oct 2018.

[29] Diwakar, S., Radhamani, R., Nizar, N., Kumar, D., Nair, B., \& Achuthan, K., "Using Learning Theory for Assessing Effectiveness of Laboratory Education Delivered via a Web-Based Platform," In International Conference on Remote Engineering and Virtual Instrumentation, pp. 639-648, Springer, Cham, Mar 2018.

[30] Uğur, B., Akkoyunlu, B., \& Kurbanoğlu, S., "Students' opinions on blended learning and its implementation in terms of their learning styles," Education and Information Technologies, vol. 16, no. 1, pp. 5-23, 2011.

[31] Altun, H., "Investigation of high school students' geometry course achievement according to their learning styles," Higher Education, vol. 9, no. 1, 2019.

[32] Küçük, M., Genç-Kumtepe, E., \& Taşc1, D., "Support services and learning styles influencing interaction in asynchronous online discussions," Educational Media International, vol. 47, no. 1, pp. 39-56, 2010.

[33] Çakıroğlu, Ü., "Analyzing the effect of learning styles and study habits of distance learners on learning performances: A case of an introductory programming course," The International Review of Research in Open and Distributed Learning, vol. 15, no. 4, 2014

[34] Parkinson, D., Greene, W., Kim, Y., \& Marioni, J., "Emerging themes of student satisfaction in a traditional course and a blended distance course," TechTrends, vol. 47, no. 4, pp. 22-28, 2003.

[35] Kayes, D. C., "Internal validity and reliability of Kolb's learning style inventory version 3 (1999)," Journal of Business and Psychology, vol. 20, no. 2, pp. 249-257, 2005.

[36] Weirstra, R. F. A., \& DeJong, J. A., "A scaling theoretical evaluation of Kolb's learning style inventory-2. In M. Valcke \& D. Gombeir (Eds.), Learning styles: reliability and validity (pp. 431-440)," Proceedings of the seventh annual European learning styles information network, Ghent, Belgium: University of Ghent, 26-28 Jun 2002.

[37] Shantakumari, N., \& Sajith, P., "Blended learning: The student viewpoint," Annals of medical and health sciences research, vol. 5, no. 5, pp. 323-328, 2015.

[38] Baykan, Z., \& Naçar, M., "Learning styles of first-year medical students attending Erciyes University in Kayseri, Turkey," Advances in physiology education, vol. 31, no. 2, pp. 158-160, 2007. 